\title{
Psychological, sociodemographic, and clinicopathological predictors of breast cancer patients' decision to undergo breast reconstruction after mastectomy
}

Azmi Marouf, Medical Student, Hatan Mortada, MBBS, Mahmoud G. Fakiha, MD, DESC.

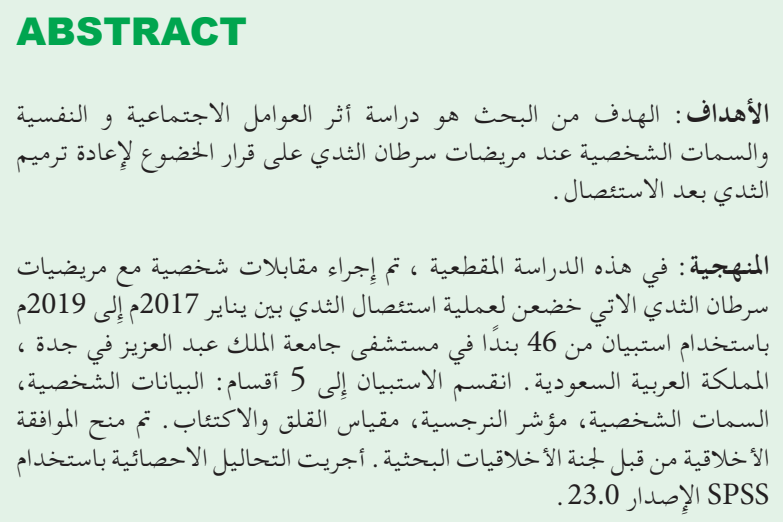

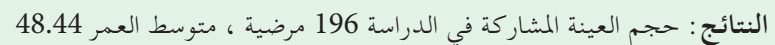

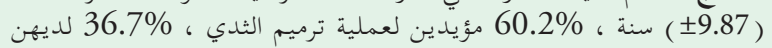

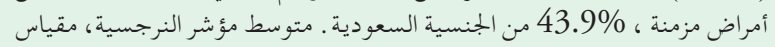

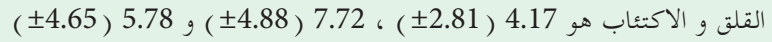

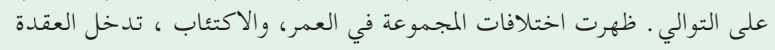

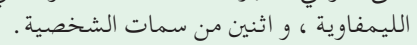

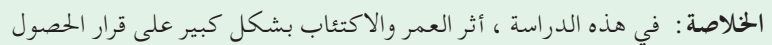

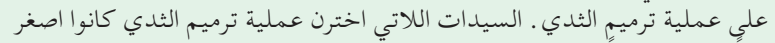

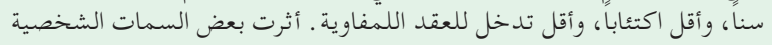

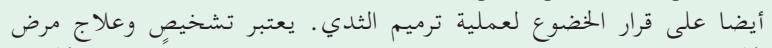

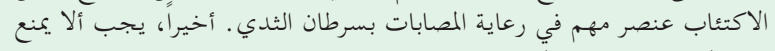

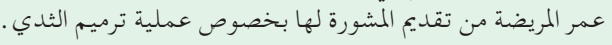

Objectives: To examine the influence of socioeconomic factors, anxiety, depression, and personality traits on the decision to undergo breast reconstruction (BR) post mastectomy.

Methods: In this cross-sectional study, adult female breast cancer (BC) patients who had undergone a mastectomy between January 2017 and 2019 were interviewed using a 46-item questionnaire at King Abdulaziz University Hospital, Jeddah, Saudi Arabia. The questionnaire was divided into 5 sections: demographic data, personality traits, the Narcissism Index (NI), and the Hospital Anxiety and Depression Scale (HADS).
Results: The sample $(\mathrm{N}=196$; mean age: 48.44 [ \pm 9.87] years, opted for BR: $60.2 \%$, with chronic diseases: $36.7 \%$, Saudi nationals: $43.9 \%$ ) obtained means of 4.17 $( \pm 2.81)$ on NI score, $7.72( \pm 4.88)$ on anxiety score, and $5.78( \pm 4.65)$ on depression score. Group differences in age, depression, lymph node involvement, and 2 personality traits emerged.

Conclusion: Age and depression significantly influenced the decision to undergo BR. Women who had opted for BR tended to be younger, be less depressed, and be characterized by lesser nodal involvement. Personality traits also influenced the decision to undergo BR. Diagnosing and treating depressed patients is an important component. A patient's age should not deter physicians from counselling them about BR.

Keywords: anxiety, breast cancer, breast reconstruction, depression, mastectomy

Saudi Med J 2020; Vol. 41 (3): 267-274 doi: 10.15537/smj.2020.3.24946

From the Faculty of Medicine (Marouf), King Abdulaziz University; from the Department of Plastic Surgery \& Burn Unit (Mortada), King Saud Medical City; and from the Division of Plastic \& Reconstructive Surgery (Fakiha), Department of Surgery, University of Jeddah, Jeddah, Kingdom of Saudi Arabia.

Received 1st November 2019. Accepted 16th January 2020.

Address correspondence and reprint request to: Dr. Hatan Mortada, Department of Plastic Surgery \& Burn Unit, King Saud Medical City Riyadh, Kingdom of Saudi Arabia. E-mail: hatanmortada@gmail.com ORCID ID: https://orcid.org/0000-0003-1283-4136

B reast cancer is the most commonly occurring cancer among females, and it affects 2.1 million women worldwide each year. ${ }^{1}$ Among Saudi women, it is the most common cancer. ${ }^{2}$ The incidence of breast cancer in the United States (US) is 124 per 100000 women. ${ }^{3}$ In many cases of breast cancer, a mastectomy is indicated. Mastectomy significantly deprives women of their sense 
of femininity and makes them feel less attractive, and this in turn adversely influences their quality of life (QOL). ${ }^{4-7}$ Postmastectomy breast reconstruction (BR) improves QOL. ${ }^{8,9}$ There are primarily 2 types of BR, namely, implant and autologous (flap) reconstruction, and each of these can be implemented through various approaches. For example, implants include saline and silicone. A flap of the latissimus dorsi or transverse rectus abdominis (TRAM) is used for autologous BR. The latissimus dorsi flap is swung from the back. It provides less fullness than TRAM, thus an implant or a fat graft is often used coupled with it. ${ }^{10}$ A TRAM flap is performed by rotating the rectus abdominis muscle or by removing a smaller part of the muscle with its skin (free flap). Free TRAM flaps provide more flexibility and lower risk of tissue necrosis when compared to pedicle TRAM flaps. ${ }^{11}$ It has been shown that autologous BR yields superior outcomes, when compared to implant BR. ${ }^{12-14}$ Nowadays, most BRs involve implants; in the late twentieth century, autologous implants were more popular. ${ }^{15}$ This change is partially attributable to surgeons' efforts to provide the option of reconstruction to the high-risk postmastectomy population (namely, patients with other comorbidities and/or those older than 60 years). ${ }^{16}$

Breast cancer patients experience psychological morbidities, primarily mood disorders, after receiving and when living with the diagnosis. The untreated anxiety and depression are important factors that render the QOL of these patients low, not merely the physical aspect of the patients' presentation. ${ }^{17,18}$ These morbidities in women with breast cancer are often overlooked and left untreated because they can have unclear presentations. ${ }^{17}$

According to the findings of a Polish study, deciding to undergo BR after breast removal is correlated with personality traits among women. Specifically, introverts rarely opted to undergo BR. ${ }^{19}$ Another important personality type is the narcissistic personality. Specifically, narcissists tend to demand perfectionism as it is a sentinel feature of their personality type; hence, they seek to have an extremely attractive body. ${ }^{20-22}$

Despite recommendations to undergo BR, the rates at which the procedure is performed are low, ranging from $11 \%$ to less than $40 \%$ (in some tertiary care centers in the US). ${ }^{23,24}$ The decision to undergo BR

Disclosure. Authors have no conflict of interests, and the work was not supported or funded by any drug company. is complicated by a variety of procedures. ${ }^{12}$ Women are asked to choose from an array of procedures, and the problem has become more strenuous with the development of the perforator flap technique, which minimizes the risk of hernia albeit requires longer operation time. ${ }^{12}$ Additionally, the burden that the surgical procedure places on the patient and her relatives makes the decision-making process even more difficult. ${ }^{25}$ Two studies that were conducted in Europe found that the patient's age influences her decision to undergo $\mathrm{BR}$ and the possession of information about the procedure. ${ }^{26,27}$

Only a small proportion of treated breast cancer patients decide to undergo BR. ${ }^{15,28}$ Therefore, it is important to examine which mood states and social aspects influence this decision-making process. In this study, we aimed to examine the influence of socioeconomic factors, anxiety, depression, and personality traits on the decision to undergo BR after a mastectomy in one center in Jeddah, Saudi Arabia.

Methods. This cross-sectional study was conducted between March and July 2019, using an interviewbased questionnaire. This interview was conducted among female patients who were diagnosed with breast cancer at King Abdulaziz University Hospital (KAUH), Jeddah, Saudi Arabia.

Women aged 18 years and older who had undergone mastectomy for breast cancer between January 2017 and 2019 were included. The exclusion criteria were as follows: a) undergone bilateral mastectomy, contralateral mastectomy for prophylactic purposes, or a reoperation and b) breast cancer recurrence. All contributors were knowledgeable before participation, and those who agreed to contribute were registered. Approximately 400 randomly chosen patients were identified from the hospital records, and 241 of them who met the study's inclusion criteria were contacted; only 196 patients agreed to participate (Figure 1). Patients were divided into 2 subgroups: Group A, which consisted of women who had opted for BR and Group B, which consisted of women who chose to not undergo BR.

Study variables. We reviewed the literature and developed a valid questionnaire based on the findings of several published studies. ${ }^{19,29-32}$ The questionnaire consisted of 46 questions that were divided into 5 sections: demographic data, personality traits, ${ }^{19}$ the Narcissism Index (NI), ${ }^{29,30}$ and the Hospital Anxiety and Depression Scale (HADS). ${ }^{31,32}$ The NI is a reliable tool for predicting the degree of narcissism. ${ }^{29,30}$ The reliability and validity of HADS on similar populations (breast cancer patients) has been studied, and it has been 


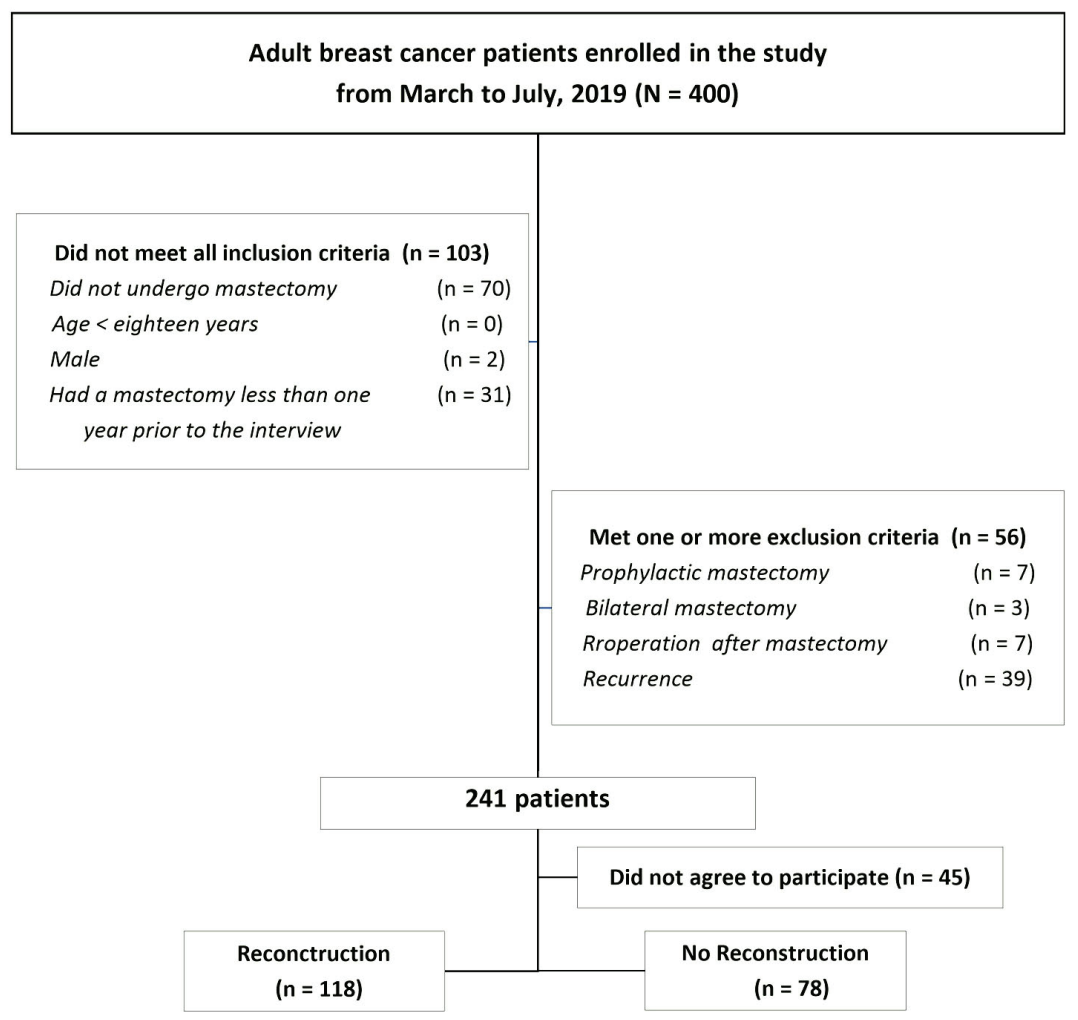

Figure 1 - Flowchart depicting the inclusion and exclusion of the study participants.

shown to have a good predictive value. Furthermore, the Arabic translation used in this study has been shown to be both valid and reliable. ${ }^{31-33}$ The study was conducted after ethical approval was granted by the Research Ethics Committee at the King Abdulaziz University Hospital. Patients participated in this study on an entirely voluntary basis.

Statistical analysis. Data were checked for completeness, and errors were corrected. The normality of the distributions of continuous variables were checked by conducting the Shapiro-Wilk and Kolmogorov Smirnov tests. Their results indicated that all variables were none normally distributed. The sociodemographic variables and clinicopathological features (namely, tumor size, lymph node involvement, and metastasisTNM) of the 2 participant groups were compared using the Chi-squared test. Respondents' scores on the NI and HADS were calculated by counting the responses. The mean scores of the 2 participant groups were compared using the Mann-Whitney U test. The relationship between TNM and anxiety and depression scores were examined using the Kruskal-Wallis test. The extroversion/introversion personality continuum of the
2 participant groups were compared using Chi-squared and fisher exact tests. Binary logistic regression analysis was conducted to identify the predictors of the decision to undergo BR. The results have been presented using tables and figures.

All analyses were conducted using the Statistical Package for Social Sciences version 23.0 (IBM, Armonk, NY, USA), and 95\% confidence intervals were computed to interpret the results.

Results. A total of 196 patients were interviewed, and $118(60.2 \%)$ of them had opted for BR; the remaining $78(39.8 \%)$ patients had not opted for BR. The mean age of the participants was $48.44( \pm 9.87)$ years. Further, $86(43.9 \%)$ patients were Saudi, the monthly income of 118 (60.2\%) patients was $<5000$ Saudi Riyals (SR). One hundred and thirty (66.3\%) patients were unemployed/housewives, 72 (36.7\%) patients had chronic illnesses, and $76(38.8 \%)$ patients had a family history of breast cancer (BC). Out of the 76 participants with a family history of BC, $71.1 \%$ had a relative who had $\mathrm{BC}$ and had undergone $\mathrm{BR}$. The 
Table 1 -Sociodemographic characteristics and clinicopathological features of the respondents split by participant group.

\begin{tabular}{|c|c|c|c|c|c|}
\hline Characteristics & Attributes & $\begin{array}{c}\text { Breast } \\
\text { reconstruction } \\
(n=118)\end{array}$ & $\begin{array}{c}\text { No breast } \\
\text { reconstruction } \\
(n=78)\end{array}$ & $\begin{array}{l}\text { Odds ratio } \\
(95 \% \mathrm{CI})\end{array}$ & $P$-value \\
\hline Age (years) & $\begin{array}{l}\text { Mean } \pm \text { SD } \\
\text { Median }\end{array}$ & $\begin{array}{r}45.44 \pm 8.66 \\
45.0\end{array}$ & $\begin{array}{r}52.97 \pm 9.90 \\
53.0\end{array}$ & & $<0.001$ \\
\hline Nationality & $\begin{array}{l}\text { Saudi } \\
\text { Non-Saudi }\end{array}$ & $\begin{array}{l}62(52.5) \\
56(47.5)\end{array}$ & $\begin{array}{l}24(30.8) \\
54(69.2)\end{array}$ & $\begin{array}{c}2.491 \\
(1.365-4.546)\end{array}$ & 0.003 \\
\hline Marital status & $\begin{array}{l}\text { Single } \\
\text { Married } \\
\text { Divorced } \\
\text { Widowed }\end{array}$ & $\begin{array}{rr}9 & (7.6) \\
93 & (78.8) \\
8 & (6.8) \\
8 & (6.8)\end{array}$ & $\begin{array}{rr}9 & (11.5) \\
57 & (73.1) \\
6 & (7.7) \\
6 & (7.7)\end{array}$ & & 0.779 \\
\hline Educational level & $\begin{array}{l}\text { Below high school } \\
\text { High school } \\
\text { Bachelor's degree } \\
\text { Master } \\
\text { PHD }\end{array}$ & $\begin{array}{rr}29 & (24.6) \\
37 & (31.4) \\
41 & (34.7) \\
6 & (5.1) \\
5 & (4.2)\end{array}$ & $\begin{array}{rr}19 & (24.4) \\
29 & (37.2) \\
25 & (32.1) \\
4 & (5.1) \\
1 & (1.3)\end{array}$ & & 0.721 \\
\hline Monthly income (Saudi Riyals) & $\begin{array}{l}<5000 \\
5000-10,000 \\
10,000-20,000 \\
>20,000\end{array}$ & $\begin{array}{r}68(57.6) \\
18(15.3) \\
24(20.3) \\
8 \quad(6.8)\end{array}$ & $\begin{array}{r}50(64.1) \\
14(17.9) \\
10(12.8) \\
4 \quad(5.1)\end{array}$ & & 0.506 \\
\hline Occupation & $\begin{array}{l}\text { Works in Jeddah } \\
\text { Works outside Jeddah } \\
\text { Unemployed }\end{array}$ & $\begin{array}{l}26(22.0) \\
14(11.9) \\
78(66.1)\end{array}$ & $\begin{array}{r}24(30.8) \\
2 \quad(2.6) \\
52(66.7)\end{array}$ & & 0.041 \\
\hline Smoking & $\begin{array}{l}\text { No } \\
\text { Yes }\end{array}$ & $\begin{array}{r}104(88.1) \\
14(11.9)\end{array}$ & $\begin{array}{r}76(97.4) \\
2(2.6)\end{array}$ & $\begin{array}{c}0.195 \\
(0.043-0.886)\end{array}$ & 0.015 \\
\hline Chronic illness & $\begin{array}{l}\text { No } \\
\text { Yes }\end{array}$ & $\begin{array}{l}88(74.6) \\
30(25.4)\end{array}$ & $\begin{array}{l}36(46.2) \\
42(53.8)\end{array}$ & $\begin{array}{c}3.422 \\
(1.863-6.287)\end{array}$ & $<0.001$ \\
\hline Family history of breast cancer & $\begin{array}{l}\text { No } \\
\text { Yes }\end{array}$ & $\begin{array}{l}70(59.3) \\
48(40.7)\end{array}$ & $\begin{array}{l}50(64.1) \\
28(35.9)\end{array}$ & $\begin{array}{c}0.817 \\
(0.452-1.474)\end{array}$ & 0.501 \\
\hline $\begin{array}{l}\text { Family member underwent BR } \\
\text { postmastectomy }\end{array}$ & $\begin{array}{l}\text { No } \\
\text { Yes } \\
\text { Don't know }\end{array}$ & $\begin{array}{rr}4 & (8.3) \\
36 & (75) \\
8 & (16.7)\end{array}$ & $\begin{array}{r}8(28.6) \\
18(64.3) \\
2 \quad(7.1)\end{array}$ & & 0.046 \\
\hline Tumor size & $\begin{array}{l}\text { Ductal carcinoma in situ } \\
\text { Breast cancer T1a-c }(\leq 2 \mathrm{~cm}) \\
\text { Breast cancer T2 } \\
\text { Breast cancer T3 } \\
\text { Breast cancer T4 }\end{array}$ & $\begin{array}{l}27(22.9) \\
33(28.0) \\
34(28.8) \\
10(8.5) \\
14(11.9)\end{array}$ & $\begin{array}{r}10(12.8) \\
31(39.7) \\
23(29.5) \\
8(10.3) \\
6(7.7)\end{array}$ & & 0.241 \\
\hline Lymph node involved & $\begin{array}{l}\text { N0 } \\
\text { N1 } \\
\text { N2 } \\
\text { N3 }\end{array}$ & $\begin{array}{l}56(47.5) \\
25(21.1) \\
20(16.8) \\
17(14.4)\end{array}$ & $\begin{array}{r}35(44.9) \\
30(38.5) \\
10(12.8) \\
3(3.8)\end{array}$ & & 0.013 \\
\hline Distant metastasis & $\begin{array}{l}\text { No } \\
\text { Yes }\end{array}$ & $\begin{array}{r}110(93.2) \\
8 \quad(6.8)\end{array}$ & $\begin{array}{r}70(89.7) \\
8(10.3)\end{array}$ & $\begin{array}{c}0.636 \\
(0.228-1.773)\end{array}$ & 0.430 \\
\hline Adjuvant therapy & $\begin{array}{l}\text { None } \\
\text { Chemotherapy } \\
\text { Chemo + endocrine therapy } \\
\text { Chemo + radio therapy } \\
\text { Chemo + radio + endocrine }\end{array}$ & $\begin{array}{l}29(24.6) \\
54(45.8) \\
6(5.1) \\
16(13.6) \\
13(11.0)\end{array}$ & $\begin{array}{rr}7 & (9.0) \\
47 & (60.3) \\
8 & (10.3) \\
8 & (10.3) \\
8 & (10.3)\end{array}$ & & 0.291 \\
\hline
\end{tabular}

Table 2 - Distribution of respondents' mean NI score, anxiety score and depression score split by participant group.

\begin{tabular}{lccc}
\hline Scores & $\begin{array}{c}\text { Breast } \\
\text { reconstruction } \\
(\mathbf{n}=118)\end{array}$ & $\begin{array}{c}\text { No breast } \\
\text { reconstruction } \\
(\mathbf{n}=78)\end{array}$ & $P$-value \\
\hline Narcissism Index Score & $4.53 \pm 2.84$ & $3.64 \pm 2.70$ & 0.030 \\
Anxiety score & $6.44 \pm 4.31$ & $9.67 \pm 5.07$ & $<0.001$ \\
Depression score & $4.49 \pm 3.97$ & $7.74 \pm 4.90$ & $<0.001$ \\
\hline
\end{tabular}

Values are presented as mean \pm SD.

${ }^{*}$ Mann-Whitney U test was carried out sociodemographic characteristics for each participant group are presented in Table 1.

The group of women who had opted for BR tended to have younger women (mean difference between the 2 groups was 7.53 years, $p<0.001$ ), fewer nonsmokers $(p=0.015)$, and more women without chronic illnesses $(p<0.001)$. Unemployed participants were less likely to have opted for BR $(p=0.041)$. With regard to the TNM classification, a lymph node involvement was 
less prominent among those who had opted for BR $(p=0.13)$ (Table 1$)$.

Personality traits and mood status. The mean depression score for all participants was $5.78( \pm 4.65)$, anxiety score $7.72( \pm 4.88)$, and NI 4.17 ( \pm 2.81$)$. Table 2 shows that anxiety $(9.67 \pm 5.07$ versus 6.44 $\pm 4.31, p<0.001)$ and depression scores $(7.74 \pm 4.90$ versus $4.49 \pm 3.97, \mathrm{p}<0.001)$ were significantly higher among participant who had opted to not undergo BR. However, scores on the NI were higher among those who had opted for BR $(p=0.030)$ (Table 2).

The responses that the 2 participant groups provided to the extroversion/introversion personality questions (total: 5 questions) are summarized in Table 3. Group comparisons revealed that there was a statistically

Table 3 - Extroversion/introversion personality continuum in the 2 study groups.

\begin{tabular}{|c|c|c|c|}
\hline $\begin{array}{l}\text { Personality questions/ } \\
\text { answers }\end{array}$ & $\begin{array}{c}\text { Breast } \\
\text { reconstruction } \\
(\mathrm{n}=118)\end{array}$ & $\begin{array}{c}\text { No breast } \\
\text { reconstruction } \\
(\mathrm{n}=78)\end{array}$ & $P$-value \\
\hline $\begin{array}{l}\text { 1) Do you seek success in life? } \\
\text { Definitely yes } \\
\text { Rather yes } \\
\text { Hard to say } \\
\text { Rather no } \\
\text { Definitely no }\end{array}$ & $\begin{array}{rr}100 & (84.7) \\
12 & (10.2) \\
4 & (3.4) \\
2 & (1.7) \\
0 & (0.0)\end{array}$ & $\begin{array}{rr}68 & (87.2) \\
4 & (5.1) \\
6 & (7.7) \\
0 & (0.0) \\
0 & (0.0)\end{array}$ & $0.254^{\ddagger}$ \\
\hline $\begin{array}{l}\text { 2) Do you have the ability to } \\
\text { motivate other people? } \\
\text { Definitely yes } \\
\text { Rather yes } \\
\text { Hard to say } \\
\text { Rather no } \\
\text { Definitely no }\end{array}$ & $\begin{array}{rr}80 & (67.8) \\
26 & (22.0) \\
8 & (6.8) \\
4 & (3.4) \\
0 & (0.0)\end{array}$ & $\begin{array}{rr}50 & (64.1) \\
20 & (25.6) \\
6 & (7.7) \\
0 & (0.0) \\
2 & (2.6)\end{array}$ & $0.216^{\ddagger}$ \\
\hline $\begin{array}{l}\text { 3) Are you open to other } \\
\text { people? } \\
\text { Definitely yes } \\
\text { Rather yes } \\
\text { Hard to say } \\
\text { Rather no } \\
\text { Definitely no }\end{array}$ & $\begin{array}{rr}74 & (62.7) \\
30 & (25.4) \\
10 & (8.5) \\
4 & (3.4) \\
0 & (0.0)\end{array}$ & $\begin{array}{r}50(64.1) \\
12(15.4) \\
8(10.3) \\
8(10.3) \\
0 \quad(0.0)\end{array}$ & $0.119^{\ddagger}$ \\
\hline $\begin{array}{l}\text { 4) Does belonging to a social } \\
\text { group have an impact of your } \\
\text { feeling of safety? } \\
\text { Definitely yes } \\
\text { Rather yes } \\
\text { Hard to say } \\
\text { Rather no } \\
\text { Definitely no }\end{array}$ & $\begin{array}{r}52(44.1) \\
22(18.6) \\
4 \quad(3.4) \\
20(16.9) \\
20(16.9)\end{array}$ & $\begin{aligned} 40 & (51.3) \\
16 & (20.5) \\
14 & (17.9) \\
6 & (7.7) \\
2 & (2.6)\end{aligned}$ & $0.002^{*}$ \\
\hline $\begin{array}{l}\text { 5) Is the opinion of other } \\
\text { people about you important } \\
\text { for you? } \\
\text { Definitely yes } \\
\text { Rather yes } \\
\text { Hard to say } \\
\text { Rather no } \\
\text { Definitely no }\end{array}$ & $\begin{array}{rr}38 & (32.2) \\
30 & (25.4) \\
8 & (6.8) \\
12 & (10.2) \\
30 & (25.4)\end{array}$ & $\begin{array}{r}36(46.2) \\
20(25.6) \\
8(10.3) \\
12(15.4) \\
2(2.6)\end{array}$ & $<0.001^{*}$ \\
\hline
\end{tabular}

${ }^{\ddagger}$ Fisher-Freemen-Halton test. ${ }^{*}$ Chi-square test significant difference in the responses that were provided to questions 4 ( $p=0.0002)$ and $5(p<0.001)$ (Table 3$)$.

Disease stage and mood status. There was no statistically significant relationship between TNM classification and anxiety and depression scores $(p>0.050)$.

Binary logistic regression. Binary logistic regression analysis was used to identify the predictors of the decision to undergo BR. Anxiety and depression scores, sociodemographic variables, TNM classification, and adjuvant treatment were included in the regression analysis. The results revealed that depression scores, age, and lymph node involvement were statistically significant predictors of BR decision. Other included variables were not statistically significant $(p>0.050)$ (Table 4).

Discussion. Among breast cancer patients, undergoing mastectomy frequently has a negative impact on the QOL and psychological well-being. Undoubtedly, this body part entails important psychological implications. Consequently, patients who have undergone a mastectomy perceive a decline their sense of femininity and confidence levels. A mastectomy without BR can alter the mood and behaviors of patients in their workspaces. ${ }^{34}$ Further, it can strongly impact their roles as a family member. Therefore, BR after breast removal can tremendously improve QOL and perceived body image. Accordingly, we aimed to examine the relationship that the decision to undergo BR shares with different personality traits, depression, anxiety and sociodemographic variables among breast cancer patients.

The existing literature suggests that age is a very important determinant on BR. ${ }^{24,26,27}$ A similar result emerged in this study. This finding is attributable to surgeons' fear of postoperative complications, especially in a patient with other chronic illnesses. ${ }^{27}$ There was a significant difference in BR status between Saudis and non-Saudis. This finding may be attributable to group differences in access to healthcare or the relatively higher mean depression $(6.47 \pm 4.96$ versus $4.91 \pm 4.04$, $p=0.035)$ and anxiety scores $(8.93 \pm 5.18$ versus $6.19 \pm$ $4.00, p<0.001)$ that non-Saudi participants obtained (the regression analysis presented in Table 4 yielded no significant predictor).

Another interesting finding was that the patients who were willing to undergo BR were healthier and did not have any chronic illnesses or comorbidities, when compared to the other group. Being healthy is closely related to happiness, and deciding to undergo such a procedure can tremendously improves a patient's 
Table 4 - Logistic regression of the predictors of the decision to undergo breast reconstruction postmastectomy.

\begin{tabular}{|c|c|c|c|}
\hline Variables & Odds ratio & $95 \% \mathrm{CI}$ & $P$-value \\
\hline Anxiety score & 0.897 & $0.786-1.024$ & 0.108 \\
\hline Depression score & 0.794 & $0.695-0.907$ & 0.001 \\
\hline Age (years) & 0.870 & $0.813-0.930$ & 0.001 \\
\hline $\begin{array}{l}\text { Nationality } \\
\text { Saudi } \\
\text { Non-Saudi }\end{array}$ & $\begin{array}{c}\text { Ref. } \\
2.082\end{array}$ & $0.722-6.005$ & 0.175 \\
\hline $\begin{array}{l}\text { Occupation } \\
\text { Unemployed } \\
\text { Works outside Jeddah } \\
\text { Works in Jeddah }\end{array}$ & $\begin{array}{l}\text { Ref. } \\
0.006 \\
0.101\end{array}$ & $\begin{array}{c}0.000032-1.138 \\
0.000435-23.453\end{array}$ & $\begin{array}{l}0.056 \\
0.410\end{array}$ \\
\hline $\begin{array}{l}\text { Monthly income (SR) } \\
\quad<5000 \\
5000-10000 \\
10000-20000 \\
>20000\end{array}$ & $\begin{array}{l}\text { Ref. } \\
0.514 \\
0.355 \\
1.030\end{array}$ & $\begin{array}{c}0.057-4.607 \\
0.033-3.816 \\
0.104-10.243\end{array}$ & $\begin{array}{l}0.552 \\
0.392 \\
0.980\end{array}$ \\
\hline $\begin{array}{l}\text { Educational level } \\
\text { PHD } \\
\text { Master } \\
\text { Bachelor degree } \\
\text { High school } \\
\text { Below high school }\end{array}$ & $\begin{array}{l}\text { Ref. } \\
0.643 \\
0.880 \\
1.567 \\
0.520\end{array}$ & $\begin{array}{l}0.076-5.491 \\
0.104-7.450 \\
0.044-55.619 \\
0.058-4.676\end{array}$ & $\begin{array}{l}0.687 \\
0.907 \\
0.805 \\
0.560\end{array}$ \\
\hline $\begin{array}{l}\text { Marital status } \\
\text { Married } \\
\text { Single } \\
\text { Divorced } \\
\text { Widowed }\end{array}$ & $\begin{array}{l}\text { Ref. } \\
0.731 \\
0.918 \\
0.349\end{array}$ & $\begin{array}{l}0.068-7.903 \\
0.166-5.084 \\
0.041-2.929\end{array}$ & $\begin{array}{l}0.797 \\
0.922 \\
0.332\end{array}$ \\
\hline $\begin{array}{l}\text { Smoking } \\
\text { No } \\
\text { Yes }\end{array}$ & $\begin{array}{l}\text { Ref. } \\
7.045\end{array}$ & $0.085-582.244$ & 0.386 \\
\hline $\begin{array}{l}\text { Chronic illness } \\
\text { No } \\
\text { Yes }\end{array}$ & $\begin{array}{l}\text { Ref. } \\
0.983\end{array}$ & $0.342-2.826$ & 0.975 \\
\hline $\begin{array}{l}\text { Tumor size } \\
\text { Ductal carcinoma in situ } \\
\text { Breast cancer T1a-c } \\
\text { Breast cancer T2 } \\
\text { Breast cancer T3 } \\
\text { Breast cancer T4 }\end{array}$ & $\begin{array}{l}\text { Ref. } \\
1.776 \\
0.632 \\
2.461 \\
1.309\end{array}$ & $\begin{array}{c}0.298-10.595 \\
0.121-3.304 \\
0.421-14.399 \\
0.156-10.955\end{array}$ & $\begin{array}{l}0.528 \\
0.587 \\
0.318 \\
0.804\end{array}$ \\
\hline $\begin{array}{l}\text { Lymph node involved } \\
\text { N0 } \\
\text { N1 } \\
\text { N2 } \\
\text { N3 }\end{array}$ & $\begin{array}{l}\text { Ref. } \\
0.217 \\
0.041 \\
0.090\end{array}$ & $\begin{array}{l}0.021-2.255 \\
0.003-0.540 \\
0.007-1.156\end{array}$ & $\begin{array}{l}0.201 \\
0.015 \\
0.064\end{array}$ \\
\hline $\begin{array}{l}\text { Distal metastasis } \\
\text { No } \\
\text { Yes }\end{array}$ & $\begin{array}{c}\text { Ref. } \\
0.756\end{array}$ & $0.165-3.464$ & 0.719 \\
\hline $\begin{array}{l}\text { Adjuvant treatment } \\
\text { None } \\
\text { Chemotherapy } \\
\text { Chemo+endocrine therapy } \\
\text { Chemo+radiotherapy } \\
\text { Chemo+radio+endocrine }\end{array}$ & $\begin{array}{l}\text { Ref. } \\
2.475 \\
0.657 \\
2.711 \\
1.424\end{array}$ & $\begin{array}{c}0.221-27.750 \\
0.086-5.008 \\
0.149-49.222 \\
0.129-15.732\end{array}$ & $\begin{array}{l}0.462 \\
0.685 \\
0.500 \\
0.773\end{array}$ \\
\hline $\begin{array}{l}\text { Family history of } B R \\
\text { Yes } \\
\text { No }\end{array}$ & $\begin{array}{l}\text { Ref. } \\
0.194\end{array}$ & $0.034-1.095$ & 0.063 \\
\hline
\end{tabular}

QOL. ${ }^{4-7,35}$ This is similar to the findings of 2 studies that were conducted in the US ${ }^{36}$ and Australia, ${ }^{37}$ whereby patients with fewer comorbidities were found to be more likely to undergo BR.

Past findings suggest that patients with early-stage BC are more likely to undergo BR. Similarly, in the present study, the percentage of node negative patients was higher in the $\mathrm{BR}$ group. It is noteworthy that many of these early stage BC patients do not require postmastectomy chemotherapy and radiotherapy. ${ }^{24}$

It is noteworthy that, in the present study, patients with a family member who had undergone BR were more likely to have opted for BR than their counterparts. This may be the case because $\mathrm{BC}$ survivors prefer to receive information about BR from their friends and peers. Further, they feel less isolated after they receive such information from patients who have undergone BR. ${ }^{38}$

In this study, the HADS was used to assess the affective states of the participants. The Center for Epidemiological Studies Depression (CES-D) Scale was not used owing to 2 primary reasons: a) it does not screen for anxiety and b) its performance and reliability has been examined primarily mostly on young population. ${ }^{39,40}$ In comparison, the HADS is a simpler assessment, and its reliability has been examined across different contexts (including among $\mathrm{BC}$ patients and cancer patients in general) and age groups. ${ }^{31-33}$ Our results suggest that women with depression and anxiety are not prepared to undergo another nonvital procedure as most of the focus is on monitoring $\mathrm{BC}$ recurrence with anxiety and depression being vaguely present. ${ }^{17}$ Satisfactory doctor-patient communication regarding patient concerns and the provision of crucial information to the patient are important factors that can improve the detection of psychological problems and mitigate depressive symptoms and anxiety among BC patients. ${ }^{18}$

The responses that the 2 groups provided to the 5 personality questions, which were adapted from the assessment that was used in a Polish study, were compared using Chi-squared and fisher exact tests (Table 3). Interestingly, 2 questions for which significant group differences had emerged in the original study had also evidenced significant group differences in the current study. ${ }^{19}$ In both the studies, patients who had opted for BR were more likely to be extroverted, as extrovert individuals are mainly outgoing and like to be with others. In the present study, the NI scores were higher among those who had opted for BR.

Study limitations. Although our sample size was moderate, and the study's objectives were addressed, the study has a few limitations. First, our article was 
cross-sectional in nature and covered a short time period. Therefore, the participants may not have been representative of the entire population of Saudi Arabia. Second, this study was conducted in a single center, thereby limiting the generalizability of the results. Third, the reliability of the 5 personality questions has not been studied. In the future, studies must include a larger number of hospitals that represent different regions within the country. This study offers insights into the prevalence of depression and anxiety among breast cancer patients after mastectomy. It also uncovers the variability in personality traits within this population. More importantly, it indicates that depression single handedly plays a significant role in the decision to not undergo BR, after potential confounds are controlled for. It is important to screen and detect undiagnosed depression and anxiety among patients who have undergone a mastectomy. This is necessary to effectively treat these conditions through prompt referral to a psychiatrist, improve their QOL, restore at least a moderate level of functioning, and provide assistance during this difficult postmastectomy decision-making period. Patients of all ages should receive counseling about BR after a mastectomy.

In conclusion, undergoing $\mathrm{BR}$ is a difficult, yet important decision for a woman who survived BC to make. Age and depression significantly influenced this decision among our study participants. Women who opted to undergo BR tend to be younger, report lower levels of depression, and were characterized by less nodal involvement. Certain personality traits can also influence the decision to undergo BR. Diagnosing and treating depressed patients is an important aspect of caring for BC patients. A patient's age should not deter physicians from counseling patients about BR.

Acknowledgment. The authors would like to thank Randa Abushanab and Renad Alnemari for their help in data collection. Also, we would like to acknowledge www. Editage.com for English language editing.

\section{References}

1. Bray F, Ferlay J, Soerjomataram I, Siegel RL, Torre LA, Jemal A. Global cancer statistics 2018: GLOBOCAN estimates of incidence and mortality worldwide for 36 cancers in 185 countries. CA Cancer J Clin 2018; 68: 394-424.

2. Saudi Health Council. Cancer Incidence Report in Saudi Arabia 2014. Available from: https://nhic.gov.sa/eServices/ Documents/2014.pdf
3. US Cancer Statistics Working Group. US Cancer Statistics Data Visualizations Tool, based on November 2017 submission data (1999-2015): US Department of Health and Human Services, Centers for Disease Control and Prevention and National Cancer Institute. Center for Disease Control and Prevention and National Cancer Institute.[Cited June 2018.] Available from URL: https://www.cdc.gov/cancer/uscs/dataviz/index. htm

4. Noyan MA, Sertoz OO, Elbi H, Kayar R, Yilmaz R. Variables affecting patient satisfaction in breast surgery: a cross-sectional sample of Turkish women with breast cancer. Int J Psychiatry Med 2006; 36: 299-313.

5. Ganz PA, Desmond KA, Leedham B, Rowland JH, Meyerowitz BE, Belin TR. Quality of life in long-term, disease-free survivors of breast cancer: a follow-up study. J Natl Cancer Inst 2002; 94: 39-49.

6. Kenny P, King MT, Shiell A, Seymour J, Hall J, Langlands A, Boyages J. Early stage breast cancer: costs and quality of life one year after treatment by mastectomy or conservative surgery and radiation therapy. Breast 2000; 9: 37-44.

7. Manganiello A, Hoga LA, Reberte LM, Miranda CM, Rocha CA. Sexuality and quality of life of breast cancer patients post mastectomy. Eur J Oncol Nurs 2011; 15: 167-172.

8 Cordeiro PG. Breast reconstruction after surgery for breast cancer. N Engl J Med 2008; 359: 1590-1601.

9. Eltahir Y, Werners LL, Dreise MM, van Emmichoven IA, Jansen L, Werker PM, de Bock GH. Quality-of-life outcomes between mastectomy alone and breast reconstruction: comparison of patient-reported BREAST-Q and other health-related qualityof-life measures. Plast Reconstr Surg 2013; 132: 201e-209e.

10. di Pompeo FS, Laporta R, Sorotos M, Pagnoni M, Falesiedi F, Longo B. Latissimus dorsi flap for total autologous immediate breast reconstruction without implants. Plast Reconstr Surg 2014; 134: 871e-879e.

11. Kroll SS, Gherardini G, Martin JE, Reece GP, Miller MJ, Evans GR, Robb GL, Wang BG. Fat necrosis in free and pedicled TRAM flaps. Plast Reconstr Surg 1998; 102: 1502-1507.

12. Yueh JH, Slavin SA, Adesiyun T, et al. Patient satisfaction in postmastectomy breast reconstruction: a comparative evaluation of DIEP, TRAM, latissimus flap, and implant techniques. Plast Reconstr Surg 2010; 125: 1585-1595.

13. Pusic AL, Matros E, Fine N, Buchel E, Gordillo GM, Hamill JB, Kim HM, Qi J, Albornoz C, Klassen AF, Wilkins EG. Patientreported outcomes 1 year after immediate breast reconstruction: results of the mastectomy reconstruction outcomes consortium study. J Clin Oncol 2017; 35: 2499-2506.

14. Saulis AS, Mustoe TA, Fine NA. A retrospective analysis of patient satisfaction with immediate postmastectomy breast reconstruction: comparison of three common procedures. Plast Reconstr Surg 2007; 119: 1669-1676.

15. Albornoz CR, Bach PB, Mehrara BJ, Disa JJ, Pusic AL, McCarthy CM, Cordeiro PG, Matros E. A paradigm shift in US breast reconstruction: increasing implant rates. Plast Reconstr Surg 2013; 131: 15-23.

16. Farhangkhoee H, Matros E, Disa J. Trends and concepts in post-mastectomy breast reconstruction. J Surg Oncol 2016; 113: 891-894.

17. Maass SW, Roorda C, Berendsen AJ, Verhaak PF, de Bock $\mathrm{GH}$. The prevalence of long-term symptoms of depression and anxiety after breast cancer treatment: a systematic review. Maturitas 2015; 82: 100-108. 
18. Turner J, Kelly B, Swanson C, Allison R, Wetzig N. Psychosocial impact of newly diagnosed advanced breast cancer. Psychooncology 2005; 14: 396-407.

19. Miśkiewicz H, Antoszewski B, Iljin A. Personality traits and decision on breast reconstruction in women after mastectomy Polish Journal of Surgery 2016; 88: 209-214.

20. Siomopoulos V. Narcissistic personality disorder: Clinical features. American Journal of Psychotherapy 1988; 42: 240-253.

21. Sorotzkin B. Understanding and treating perfectionism in religious adolescents. Psychotherapy: Theory, Research, Practice, Training 1998; 35: 87.

22. Smith MM, Sherry SB, Chen S, Saklofske DH, Flett GL, Hewitt PL. Perfectionism and narcissism: A meta-analytic review. J Res Pers 2016; 64: 90-101.

23. Oh DD, Flitcroft K, Brennan ME, Spillane AJ. Patterns and outcomes of breast reconstruction in older women-a systematic review of the literature. Eur J Surg Oncol 2016; 42: 604-615.

24. Brennan ME, Spillane AJ. Uptake and predictors of postmastectomy reconstruction in women with breast malignancysystematic review. Eur J Surg Oncol 2013; 39: 527-541.

25. Somogyi RB, Webb A, Baghdikian N, Stephenson J, Edward $\mathrm{KL}$, Morrison W. Understanding the factors that influence breast reconstruction decision making in Australian women. Breast 2015; 24: 124-130.

26. Lardi AM, Myrick ME, Haug M, Schaefer DJ, Bitzer J, Simmen U, Güth U. The option of delayed reconstructive surgery following mastectomy for invasive breast cancer: Why do so few patients embrace this offer?. Eur J Surg Oncol 2013; 39: 36-43.

27. Héquet D, Zarca K, Dolbeault S, Couturaud B, Ngô C, Fourchotte $\mathrm{V}$, et al. Reasons of not having breast reconstruction: A historical cohort of 1937 breast cancer patients undergoing mastectomy. Springerplus 2013; 2: 325.

28. Harcourt D, Rumsey N. Psychological aspects of breast reconstruction: a review of the literature. J Adv Nurs 2001; 35: 477-487.

29. Raskin R, Terry H. A principal-components analysis of the Narcissistic Personality Inventory and further evidence of its construct validity. J Pers Soc Psychol 1988; 54: 890.
30. Ames DR, Rose P, Anderson CP. The NPI-16 as a short measure of narcissism. J Pers Soc Psychol 2006; 40: 440-450.

31. Zigmond AS, Snaith RP. The hospital anxiety and depression scale. Acta Psychiatr Scand 1983; 67: 361-370.

32. Terkawi AS, Tsang S, AlKahtani GJ, Al-Mousa SH, Al Musaed S, AlZoraigi US, Alasfar EM, Doais KS, Abdulrahman A, Altirkawi KA. Development and validation of Arabic version of the Hospital Anxiety and Depression Scale. Saudi J Anaesth 2017; 11 (Suppl 1): S11.

33. Bjelland I, Dahl AA, Haug TT, Neckelmann D. The validity of the Hospital Anxiety and Depression Scale: an updated literature review. J Psychosom Res 2002; 52: 69-77.

34. Keesing S, Rosenwax L, McNamara B. The implications of women's activity limitations and role disruptions during breast cancer survivorship. Women's Health 2018; 14: 1745505718756381.

35. Offodile AC, Wenger J, Guo L. Relationship between comorbid conditions and utilization patterns of immediate breast reconstruction subtypes post-mastectomy. The Breast Journal 2016; 22: 310-315.

36. Reuben BC, Manwaring J, Neumayer LA. Recent trends and predictors in immediate breast reconstruction after mastectomy in the United States. Am J Surg 2009; 198: 237-243.

37. Hall SE, Holman CD. Inequalities in breast cancer reconstructive surgery according to social and locational status in Western Australia. Eur J Surg Oncol 2003; 29: 519-525.

38. Webb C, Sharma V, Temple-Oberle C. Delivering breast reconstruction information to patients: Women report on preferred information delivery styles and options. Plast Surg (Oakv) 2018; 26: 26-32.

39. Pretorius TB. Cross-cultural application of the Center for Epidemiological Studies Depression Scale: A study of black South African students. Psychol Rep 1991; 69 (3 Pt 2): 1179-1185.

40. Iwata N, Buka S. Race/ethnicity and depressive symptoms: a cross-cultural/ethnic comparison among university students in East Asia, North and South America. Soc Sci Med 2002; 55 : 2243-2252. 